\title{
SPEECH DIFFICULTIES AND POOR SPEECH INTELLIGIBILITY IN ADULTS WITH DOWN SYNDROME: A REVIEW OF THE LITERATURE
}

\author{
Marjolein C. Coppens-Hofman' ${ }^{1}$, Ben A.M. Maassen², \\ Henny M.J. van Schrojenstein Lantman-de Valk ${ }^{3}$, Ad F.M. Snik ${ }^{4}$
}

${ }^{1}$ Radboud University Nijmegen Medical Centre - Department of Medical Psychology and NCEBP

${ }^{2}$ University of Groningen, Centre for Language and Cognition (CLCG)

${ }^{3}$ Radboud University Nijmegen Medical Centre - Department of Primary and Community Care

${ }^{4}$ Radboud University Nijmegen Medical Centre - Department of Otorhinolaryngology and Donders Institute for Brain, Cognition and Behaviour

Corresponding author: Marjolein C. Coppens-Hofman, Radboud University Nijmegen Medical Centre, Department of Medical Psychology, Postbus 9101, 6500 HB Nijmegen, The Nederlands,

Tel.: +31 64987 4481, e-mail: m.coppens@mps.umcn.nl

\section{Abstract}

Background: This review gives an overview of studies on speech difficulties in adults with Down syndrome to identify causes and major determinants of poor speech intelligibility for this group and to suggest areas requiring further research.

Material and Methods: Exactly 39 published articles were selected by using the following MEsH search terms: speech disorders, articulatory apraxia, phonological impairment, articulation disorders, short-term memory, speech articulation disorders, and speech intelligibility. Articles were grouped for analysis based on themes related to underlying causes of speech difficulties and the diagnosis and treatment of speech difficulties. Future research needs are also presented.

Results: Speech problems in adults with Down syndrome are not clearly defined. There is no specific data on underlying mechanisms that negatively impact on speech and there is no systematic assessment procedure available for evaluating the speech of adults with Down syndrome. Few studies have investigated treatment possibilities for speech disorders in adults and future research is needed into speech difficulties in adults with Down syndrome.

Conclusions: Research is required into therapeutic programs to improve the speech of adults with Down syndrome. One clinical consideration as to why this research is lacking might be that the speech problem is seen as a characteristic of the Down syndrome itself rather than being seen as the result of distinct underlying deficits that may be sensitive to speech therapy. To aid therapeutic program development, longitudinal studies of adolescents and adults with Down syndrome are required. Special attention could be given to investigating oral-motor characteristics and apraxia of speech.

Key words: Down syndrome • speech disorders • articulatory apraxia • phonological impairment • articulation disorders • short-term memory $\bullet$ speech articulation disorders $\bullet$ speech intelligibility

\section{НАРУШЕНИЯ РЕЧИ И НЕРАЗБОРЧИВОСТЬ РЕЧИ У ВЗРОСЛЫХ С СИНДРОМОМ ДАУНА: ОБЗОР ЛИТЕРАТУРЫ}

\section{Резюме}

Введение: Данная работа представляет собой обзор литературы по теме нарушений речи у взрослыхс синдромом Дауна. Целью является установление причин и основных состовляющих неразборчивости речи в данной группе и рекомендация областей, нуждающихся в дальнейших исследованиях.

Материалы и методы: Было выбрано 39 опубликованных статей в MEsH при использовании следующих поисковых слов: нарушения речи, артикулярная апраксия, фонологическое расстройство, нарушения артикуляции, краткосрочная память, речевые нарушения артикуляции и речевая разборчивость. Статьи были сгруппированы для анализа на основании тем, связанных с первопричинами нарушений речи и лечением речевых трудностей. Цели будущих исследований также представлены.

Результаты: Речевые проблемы у взрослых с синдромом Дауна четко не определены. Не существует определенных данных, которые бы выделяли механизмы, отрицательно воздействующие на речь, а так же нет систематической процедуры, доступной для оценки речи взрослых с синдромом Дауна. Небольшое количество научных 
работ исследовало возможности лечения речевых нарушений у взрослых. Существует необходимость проведения в будущем исследования, которое изучило бы речевые нарушения у взрослых с синдромом Дауна.

Заключение: Исследование может приминяться в терапевтических программах, в целях улучшения речи взрослых с синдромом Дауна. Клиническим выяснением недостатка исследований данного типа может быть то, что речевая проблема рассматривается как особенная черта синдрома Дауна, а не результат определенного недостатка, который может быть поддатлив к логопедии. Чтобы помочь развитию терапевтической программы, необходимы длительные исследования подростков и взрослых с синдромом Дауна. Особое внимание может быть уделено исследованию устно-моторных особенностей и апраксии речи.

Ключевые слова: синдром Дауна • речевые нарушения • артикуляционная апраксия • фонологическое расстройство • нарушения артикуляции • краткосрочная память • речевые нарушения артикуляции • речевая разборчивость

\section{DIFICULTADES DE DISCURSO E INTELIGIBILIDAD DE DISCURSO EN ADULTOS CON ABAJO SÍNDROME: UNA REVISIÓN DE LA LITERATURA}

\section{Extracto}

Introducción: Esta revisión presenta una descripción de la litaratura sobre las dificultades de discurso en adultos con el Abajo síndrome para identificar causas y determinantes principales de la inteligibilidad de discurso en este grupo y sugerir áreas que requieren nuevas investigaciones.

Materiales y métodos: Exactamente 39 artículos publicados fueron seleccionados usando los términos siguientes de búsqueda de MEsH: desordenes de comunicación, apraxia articulatoria, desorden fonológico, desórdenes de articulación, memoria a corto plazo, desórdenes de articulación en comunicación, e inteligibilidad del discurso. Los artículos fueron agrupados para el análisis basando en temas relacionados con las causas de los dificultades del discurso y el diagnóstico y tratamiento de dificultades de discurso. Las futuras necesidades de investigación también son presentadas.

Resultados: Los problemas de discurso que tienen los adultos con el Abajo síndrome no son claramente definidos. No hay ningunos datos específicos que presentan los mecanismos que negativamente influyen el discurso y no hay ningún procedimiento de evaluación sistemático para evaluar el discurso de adultos con el Abajo síndrome. Pocos estudios han investigado posibilidades de tratamiento de desórdenes de discurso en adultos y la futura investigación de dificultades de discurso en adultos con el Abajo síndrome es necesaria.

Conclusiones: La investigación es necesaria para los programas terapéuticos que pueden mejorar el discurso de adultos con el Abajo síndrome. Una consideración clínica que puede mejorar la investigación es que el problema de discurso debe ser visto no sólo como una característica del Abajo síndrome pero también como el resultado de déficits que pueden ser sensibles a la terapia del habla. Para ayudar al desarrollo del programa terapéutico, los estudios longitudinales de adolescentes y adultos con el Abajo síndrome son necesarias. La atención especial puede ser prestada a la investigación de características motores orales y apraxia del discurso.

Palabras claves: Abajo síndrome • desordenes de comunicación • apraxia articulatoria $\bullet$ daño fonológico $\bullet$ desórdenes de articulación • memoria a corto plazo • desórdenes de articulación en comunicación • inteligibilidad del discurso

\section{Background}

Speech intelligibility is an important prerequisite for effective communication. Adequate communication skills contribute to independence, self-confidence, and social involvement. People with Down syndrome have an increased incidence of hearing loss and speech and language difficulties $[1,2]$; a widespread problem is speech intelligibility which starts in childhood and remains in adulthood [1,3-9].

Down syndrome, a genetic condition where a person has an additional chromosome (trisomy 21), occurs in approximately 1 in every 800 live births. Some $80 \%$ of individuals with Down syndrome have a mild to moderate intellectual disability [10] and, as such, it is the most frequent genetic cause of mild to moderate intellectual and developmental disabilities. The condition also has associated medical problems $[10,11]$ and is associated with a variety of physical and behavioral characteristics, such as delayed language development, chronic otitis media, abnormalities in the immune and endocrine systems, and defects of the skeletal, heart, and digestive systems. Problems with speech production were mentioned by Landon in 1866 in the first known description of this syndrome. See also $[9,11,12]$.

At the beginning of the $20^{\text {th }}$ century, life expectancy of people with Down syndrome was approximately 9 years; however, current life expectancy is approximately 50 years. With this increase in lifetime, the needs of adults with Down syndrome require attention. With assistance from family and caregivers, many adults with Down syndrome have developed the skills required to hold jobs and to live semi-independently.

Although communication skills are crucial for adult social functioning [10], little is known about the level of 
Table 1. Overview of search strategy and exclusions.

\begin{tabular}{|c|c|c|c|c|}
\hline Search term & $\begin{array}{l}\text { Number } \\
\text { of titles } \\
\text { found }\end{array}$ & $\begin{array}{l}\text { Number } \\
\text { of titles } \\
\text { excluded }\end{array}$ & Reasons for exclusion & $\begin{array}{l}\text { Number } \\
\text { of titles used } \\
\text { in review }\end{array}$ \\
\hline Speech disorders & 21 & 5 & $\begin{array}{l}\text { 3: Addressing dementia or other syndromes } \\
\text { 1: Single case-report } \\
\text { 1: Addressing only expressions of parents }\end{array}$ & 16 \\
\hline Articulatory apraxia & 3 & 0 & - & 3 \\
\hline $\begin{array}{l}\text { Phonological } \\
\text { impairment }\end{array}$ & 5 & 3 & $\begin{array}{l}\text { 1: Addressing other syndromes } \\
\text { 2: Addressing reading skills in children with DS }\end{array}$ & 2 \\
\hline Short-term memory & 24 & 6 & $\begin{array}{l}\text { 3: Addressing aphasia or dementia, } \\
\text { schizophrenia } \\
\text { 2: Addressing other syndromes } \\
\text { 1: About long-term memory only }\end{array}$ & 18 \\
\hline $\begin{array}{l}\text { Speech articulation } \\
\text { disorders }\end{array}$ & 28 & 3 & $\begin{array}{l}\text { 1:Addressing other syndromes } \\
\text { 2: Irrelevant topics }\end{array}$ & 25 \\
\hline Speech intelligibility & 4 & 1 & 1: Addressing other syndromes & 3 \\
\hline Subtotal & 85 & 18 & & 67 \\
\hline
\end{tabular}

intelligibility and speech skills for adults with Down syndrome. Unlike children who typically develop $100 \%$ intelligible speech by age four, people with Down syndrome do not reach this level of speech intelligibility at any age [7]. Anatomy and physiological changes related to the syndrome cause poor speech intelligibility.

This literature review provides the reader with an overview of studies on speech difficulties and the causes of poor speech intelligibility in adults with Down syndrome. This review is part of a large, multidisciplinary research project on communication in adults with intellectual disabilities. This larger study has been approved by the corresponding Ethics Committee as meeting the Code of Ethics of the World Medical Association (Declaration of Helsinki).

\section{Material and Methods}

Electronic searches were conducted in PubMed and in Scopus databases. We selected search terms from the International Classification of Functioning, Disability and Health and $\mathrm{MeSH}$ that are relevant to speech intelligibility: speech disorders, articulatory apraxia, phonological impairment, articulation disorders, speech articulation disorders and speech intelligibility combined with the search terms adult and Down syndrome. The search term short term memory was also included as short-term memory has an effect on learning speech and language. A separate review has been written on 'hearing loss and auditory processing disorders in adults with Down syndrome'

\section{Inclusion criteria}

We limited our search to articles published from 1 January 1987 to 1 July 2011. Articles had to be written in English.

\section{Exclusion criteria}

Table 1 presents an overview of the number of identified articles and article exclusion. We excluded articles about syndromes other than Down syndrome as well as single case studies.

In total, 85 articles were identified. After excluding 18 articles due to non-relevance to our research question, 67 titles of articles remained from the first search. Eight articles were repeated on three search terms and four articles were repeated on four different search terms. The total number of included articles was 39 (67 minus 28).

\section{Results}

We discuss the results of the remaining 39 articles from the database search and present our findings under several broad topics.

\section{Anatomical, physiological, and neurological factors}

In this section we describe major anatomical, physiological, and neurological factors associated with Down syndrome that impact or might impact on speech production.

\section{Hearing loss}

The first factor that affects speech production in persons with Down syndrome is the high prevalence of hearing loss. The main reason for hearing loss in this population is otitis media [13]. Hypoplasia of the face causes abnormality in the nasopharyngeal area: the abnormal shape and the low muscle tone in the face leads to suboptimal functioning of the Eustachian tube [14]. Two articles suggested that longer periods of otitis media might delay the development of speech and language $[9,15]$. Two studies reported that hearing impairment (due to either conductive or sensorineural hearing loss) was related to difficulties in speech intelligibility $[16,17]$.

Changes to oral and oral-motor structures

Anatomical and physiological impediments in the oral structures can impact on speech production. There are a 
number of reasons why speech production in this population is poor: deficient growth of the bones of the head and face, underdeveloped maxilla bones and smaller, wider mandibles, and reduced space in the oral cavity leading to a tongue that does not fit well in the oral cavity [18]. Reduced nasal resonance due to chronic respiratory infections and hypotonia of the specific speech muscles limit lip movements and can affect pronunciation of some consonants.

There are also several other organic characteristics of people with Down syndrome that hinder their speech [18]. In a recent study investigating movement control in two adults with Down syndrome [19], results indicated that differences in movement control may contribute significantly to intelligibility deficits.

Hyperextendable joints and a limited range of motion were two additional factors identified in the literature that affect speech production $[1,11,20]$. One article highlighted that an open mouth, drooling, and differences in respiration can also play a role [18].

\section{Neurological characteristics}

The central and peripheral nervous system of persons with Down syndrome have two distinguishing elements: the volume and weight of the brain is lower and the sulci are fewer and smaller.

Research by Welsh and colleagues [21,22] showed that adults with Down syndrome have reverse lateralisation for the perception of speech sounds - that is, a left ear and right hemisphere dominance (in short: a left ear advantage) - which has been confirmed in dichotic listening tasks and MRI studies. Elliott and colleagues [23] developed a model of neuropsychological evidence indicating that persons with Down syndrome exhibit atypical right hemispheric specialisation for speech perception and left hemisphere specialisation for motor control. Based on this model, the researchers predicted that persons with Down syndrome would have difficulty with tasks that involve speech perception as well as organisation and control of sequential movements, including speech.

Tasks that combine speech perception with organisation and control of speech movements require good interaction between the two brain hemispheres. Disruption or reversal in cerebral specialisation for speech perception, in combination with poor specialisation of the left hemisphere for speech production and the overall organisation of movement, may contribute to difficulties in speech production $[23,24]$. Malfunction of this complicated dynamics could lead to loss or degradation of information [25].

In more recent research, rather than speech-specific abnormalities general lateralisation abnormalities were found [26]. In speech-specific abnormalities, researchers report apraxia of speech, defined as difficulty in executing motor programming of speech movements, and dysarthria, defined as weakness or discoordination of the articulators that result in slow, weak, imprecise, or uncoordinated speech [18]. Researchers also report facial hypotonia (low muscle tone), changes in innervation, lower speech rate, and a reduction in the precision of speech movements [1]. Difficulties with coordinating tongue muscles and lip tension might lead to problems in articulation [9]. Three studies also mention difficulties with coordinating speech articulators $[1,11,20]$ leading to speech production disorders.

\section{Developmental issues and persistence of speech difficulties}

Roberts and colleagues [15] describe the speech of adults with Down syndrome as generally containing: (1) cluster reduction (consonant sequences are reduced by omission of one or more consonants); (2) final consonant deletion (consonants at the ends of words are omitted); (3) unstressed syllable omission, mostly at the start of a multi-syllabic word; and (4) consonant substitution (an incorrect consonant is produced, such as fricatives and affricates are produced as stops, /r/ and /l/ are produced as /w/, and consonants produced at the back of the mouth are substituted by frontal consonants). The authors also noted that the pattern of speech errors is inconsistent.

Some articles on adult speech included developmental information on speech production of children with Down syndrome. For example, in a study by van Borsel [12] focusing on consonant and vowel production (monophthongs and diphthongs) of adolescents and adults with Down syndrome, it was found that articulation difficulties mainly occurred in the phonemes that are acquired in the final phase of speech-language development in typically developing younger children.

This contrasts with the early development of speech and language skills for children with Down syndrome, which, although delayed, develops in the expected developmental sequence. This was reported for babbling [9]. The first real difficulties with speech emerge in meaningful speech. The onset of meaningful speech may be delayed by many months and further development of speech is slow, and inconsistent sound productions can occur [18].

Kumin [6] analysed data from 937 parent questionnaires on speech intelligibility of children with Down syndrome. In $95 \%$ of cases, parents reported that their child had difficulty being understood; in only $5 \%$ of all cases did parents report that their child rarely or never had any difficulties being understood. Parents reported difficulties in the domain of oral motor skills, motor programming skills, and specific speech skills. Intelligibility difficulties were more frequent when the child was conversing with unfamiliar adults as compared to caregivers. Intelligibility is a widespread problem according to Kumin [6].

By the age of eight, speech production patterns are still delayed and intelligibility is poor. Roberts and colleagues [15] reported that, compared to younger boys of the same mental age, preschool- and school-aged boys with Down syndrome had delayed speech sound development, produced more sound errors, and produced more unusual error patterns on a single word articulation test.

Phonological impairment is often reported in children with Down syndrome [11,20] and Kumin [8] pointed out 
that in children with Down syndrome, speech problems might often be caused by apraxia. In clinical practice, childhood apraxia of speech is not recognised in children with Down syndrome [8] and because the apraxia is often not diagnosed, no treatment is ever provided, so problems remain lifelong. Childhood apraxia of speech is considered a neuro-motor difficulty in learning speech movement patterns. These difficulties are not naturally resolved as the child becomes older and speech intelligibility remains a problem throughout life [16]. Remarkably, little detail is known about the exact nature of mis-articulations in adults with Down syndrome to confirm these findings. What we do know is that there seems to be a relationship between speech-motor development and language development [1].

Two factors are reported to contribute to the persistence of poor speech intelligibility through adolescence and adulthood: auditory feedback and left-ear hearing advantage. Relevant anatomical and physiological problems are described in section 3.1 of this review article. Poor auditory feedback is due to deficient auditory processing in combination with chronic hearing difficulties [1]. Keller-Bell \& Fox [27] showed that individuals with Down syndrome have greater difficulty discriminating certain types of perceptual contrasts. The reported relationship between leftear advantage and speech errors could be a reflection of a different cerebral specialisation and brain development [22]. Left-ear advantage means that the right hemisphere of the brain becomes dominant. The exact prevalence of deviating hemisphere specialisation is, however, unknown [21]

\section{Aspects of memory}

According to Jarrold and colleagues [28], persons with Down syndrome show an inferior short-term memory for verbal tasks. They examined the effect of auditory problems on performance by contrasting memory for aurally presented material with that for material presented both aurally and visually. Influence of speech-motor difficulties was studied by employing both a traditional recall procedure and a serial recognition procedure that reduced spoken response demands. Two main results were found. Firstly, impaired verbal short-term memory performance for their level of receptive vocabulary, and secondly, this deficit was specific to memory for verbal information and was not primarily caused by auditory or speech-production difficulties.

Memory has an important influence on the development and storage of language and speech; it stores the pronunciation of phonemes and, via feedback, monitors production to improve intelligibility. Some studies reported more memory errors by adults with Down syndrome compared to other adults.

In a series of experiments, researchers investigated the influence of speech-motor difficulties in both a traditional recall procedure and a serial recognition procedure that reduced spoken response demands [28-30]. Individuals with Down syndrome showed impaired short-term memory performance for receptive vocabulary. This deficit was specific to memory for verbal information and was not primarily caused by auditory or speech-production difficulties. This problem might reflect a problem of phonological storage rather than inefficient rehearsal (which is not the prime cause of impairment of verbal short-term memory in Down syndrome). Jarrold and colleagues [30] also showed that aspects of speeded articulation were delayed among individuals with Down syndrome, a factor which could not account for the severity of impairment in their verbal short-term memory performance.

A study by Bunn and colleagues [25] showed that persons with Down syndrome tend to make more speech production errors in a word imitation task, which is related to short-term memory abilities. Purser \& Jarrold [31] showed that individuals with Down syndrome do not show atypically rapid item loss from phonological memory, but may have a limited capacity of their verbal short-term memory system. Brock \& Jarrold [32] provided strong evidence that Down syndrome is associated with a selective deficit in verbal short-term memory, and in particular a deficit in verbal serial order memory. Carlesimo and colleagues [33] showed that children with Down syndrome are particularly deficient in organising verbal material according to its categorical structure and in actively retrieving stored information. These children displayed significantly lower long-term memory performances than normal.

Laws \& Bishop [34] found weak language profiles, comparable to the profiles often found in persons with specific language impairment (SLI) in adolescents with Down syndrome. The researchers concluded that impaired phonological memory was one of the main causes. According to Laws [35], Laws \& Gunn [36], and Laws \& Gunn [37], phonological memory shows a stronger association with expressive language abilities of adolescents and adults than hearing loss, but only if hearing thresholds are low or when hearing loss is corrected by hearing aids. Laws and his team concluded that more research is needed to establish the nature of these relationships. If research should show that phonological memory has a causal role in expressive language development, this might yield a starting point for treatment.

Kittler and colleagues [38] examined semantic and phonological loop effects on verbal working memory among middle-age adults with Down syndrome, and those with unspecified intellectual disabilities, in the context of Baddeley's working memory model. The results showed that, compared to their peers, participants with Down syndrome had poorer recall in all categories except phonologically similar words.

\section{Memory development}

Vicari [39] studied memory development and intellectual disabilities comparing groups with Down syndrome, Williams syndrome, and normal intelligence age-matched controls. With regard to explicit memory abilities, people with Down syndrome obtained lower performance scores than the other two groups. More recently, Conners and colleagues [40] tried to improve the memory span of children with Down syndrome by means of a training procedure using overt cumulative rehearsal and auditory-only procedures. Little improvement was seen in digit span and no improvement was seen in sentence memory and verbal working memory. However, the authors reported a side effect: a relationship was seen in increased phonological 
coding and memory training. The authors suggest that individuals with Down syndrome might improve their auditory verbal memory span through rehearsal training.

Short-term memory and verbal memory highly affect speech and language, and both these aspects are different or impaired in people with Down syndrome. We have to take this into account when investigating the causes and persistence of speech problems and when developing treatment options and goals.

\section{Methods for diagnosing speech problems}

Formal assessment

No definite assessment procedure is available for adults with Down syndrome for diagnosing underlying mechanisms of speech difficulties. In clinical practice, speech tests for children are mostly used to assess articulation and speech production in adults. In adults with Down syndrome, the correct diagnosis of disorders like apraxia of speech is too often missed at an early age.

However, one article did discuss the 'Oral Speech Motor Protocol' of Robbins and Klee (1987), an assessment procedure for adolescents with Down syndrome. This protocol requires direct observation of the major vocal tract structures and their functioning during speech and non-speech (oral) tasks. The test includes normative information for children from the ages of 2 to 6 years and has been used in testing speech in adolescents with Down syndrome. Unfortunately, no data were found for adults [20].

\section{Survey}

Two studies reported results from a parent-completed survey to collect information on prevalence and causes of poor speech intelligibility [6,8], and Kumin [8] found a significant correlation between the diagnosis of childhood apraxia of speech and intelligibility ratings given by the parents. $\mathrm{Ku}-$ min [6] reported that $15 \%$ of children with Down syndrome that had speech problems also had a diagnosis of apraxia of speech; yet for $60 \%$ of these children with speech problems and no diagnosis of apraxia, parents reported that their child had impaired oral motor skills. It is likely there are many children having Down syndrome with undiagnosed apraxia of speech and therefore it is likely that there is a large population of adults with undiagnosed apraxia of speech.

Childhood apraxia of speech results in lower speech intelligibility; however, as there is no conclusive diagnostic test for adults with Down syndrome, we can only speculate on the prevalence of apraxia in the adult population and on its impact on speech intelligibility. Evaluation instruments are mainly descriptive and rely on speech analysis and speech sound imitation skills. A diagnosis of apraxia of speech for people with Down syndrome is generally made in middle childhood or adolescence when valuable treatment time has been lost.

\section{Treatment}

Communicative interventions for people with Down syndrome mainly aim at improving expressive and receptive language rather than speech production. The speech production problems in adults with Down syndrome are often seen as a problem taken for granted [42]. No validated treatment methods are available for improving speech of people with Down syndrome. This might also be caused by a lack of diagnostic assessment procedures for the cause of their speech problems.

It is unclear if developing specific treatments to improve the speech of adults with Down syndrome would benefit this group of speakers. Many researchers have claimed that the skills begin to plateau when a child with Down syndrome reaches adolescence. However, three recent studies have shown that adolescents and adults with Down syndrome can benefit from language intervention programs like was seen at the University of Wisconsin-Madison $[4,16,41,43]$. The longitudinal study by Chapman and her research team showed that language skills continued to improve beyond the teenage years, and suggests that language-learning programs for adolescents and young adults with Down syndrome could be effective.

\section{Discussion and Conclusions}

This review had three aims: (1) to provide an overview of the studies on speech difficulties leading to poor speech intelligibility in adults with Down syndrome; (2) to identify causes of poor speech intelligibility for this group; and (3) to suggest areas requiring further research.

While modern advances in medical sciences have improved the health of children with Down syndrome, a concern remains about the development of communication skills. Studies have demonstrated that adolescents and adults with Down syndrome can learn new speech/ language skills and suggest that interventions could be effective at any age. In order to develop effective treatment programs to improve oral communication and intelligibility of speech, problems in speech development and the persistence of speech difficulties need to be investigated. Most studies on Down syndrome in relation to speech production mainly concern children under the age of 15 years [12] and results suggest that, without intervention, speech will not improve in adulthood.

If speech intelligibility is not high enough to support verbal-only communication, augmentative or alternative communication might be considered [1]. Given that $97 \%$ of all people with Down syndrome use speech as their main form of communication, and that speech production and speech perception are ongoing issues which may limit community participation, it is clear that developing assessments for evaluating speech production and intelligibility, and developing interventions to improve verbal communication, are of major importance.

Where hearing loss is a barrier to improving intelligibility, the first step has to be the rehabilitation of hearing. Rehabilitation should involve both hearing-aid fitting and auditory training. Regular hearing screening to monitor any changes in hearing status remains of great importance.

As speech and language skills are central to the development of mental abilities (such as thinking, reasoning, 
and remembering) and to social inclusion, it is essential that caregivers, teachers/mentors, and therapists discuss speech and language development at all stages of an individual's life. Considering the constant changes in the brain, its plasticity, and the development of behavioral and social skills in this group, it does not seem justified to use the same diagnostic procedures and treatment programs for children for adults.

Research is required into therapeutic programs to improve the speech of adults with Down syndrome. One clinical consideration as to why this research is lacking might be that the speech problem is seen and described as a characteristic of the Down syndrome itself rather than being seen as the result of distinct underlying deficits that may be sensitive to speech therapy. To aid therapeutic program development, longitudinal studies of adolescents and adults with Down syndrome are required to determine the developmental progression of speech and language. Special attention should be given to investigating oral-motor characteristics and apraxia of speech.

\section{Declaration of interest}

The authors report no conflicts of interest. The authors alone are responsible for the content and writing of the paper.

\section{Acknowledgements}

The authors thank R. Clapham for her suggestions and advice.

\section{References:}

1. Roberts JE, Price J, Malkin C: Language and communication development in Down syndrome. Ment Retard Dev Disabil Res Rev, 2007; 13(1): 26-35

2. NIDCD National Institute on Deafness and Other Communication Disorders, URL $h t t p: / / w w w . n i d c d . n i h . g o v$

3. Buckley S: Speech, language and communication for individuals with Down syndrome. Downs Syndr Res Pract, 2002; 8(1): v-vii

4. Chapman RS: Language learning in Down syndrome: the speech and language profile compared to adolescents with cognitive impairment of unknown origin. Downs Syndr Res Pract, 2006; 10(2): 61-66

5. Chapman RS, Seung HK, Schwartz SE, Kay-Raining Bird E: Language skills of children and adolescents with Down syndrome: II. Production deficits. J Speech Lang Hear Res, 1998; 41(4): 861-73

6. Kumin L: Intelligibility of speech in children with Down syndrome in natural settings: parents' perspective. Percept Mot Skills, 1994; 78(1): 307-13

7. Kumin L: Maximizing speech and language in children and adolescents with Down syndrome. Down Syndrome - Visions for the $21^{\text {st }}$ Century, 2002; 407-19

8. Kumin L: Speech intelligibility and childhood verbal apraxia in children with Down syndrome. Downs Syndr Res Pract, 2006; 10(1): 10-22

9. Stoel-Gammon C: Down syndrome phonology: developmental pattern and intervention strategies. Downs Syndr Res Pract, 2001; 7(3): 93-100

10. NICHD National Institute of Child Health and Human Development, Centers for Disease Control and Prevention. (2006). URL http://www.nichd.nih.gov

11. Barnes E, Roberts J, Long SH et al: Phonological accuracy and intelligibility in connected speech of boys with fragile X syndrome or Down syndrome. J Speech Lang Hear Res, 2009; 52(4): 1048-61

12. van Borsel J: Articulation in Down syndrome adolescents and adults. Eur J Disord Commun, 1996; 31(4): 415-44

13. Shott SR, Joseph A, Heithaus D: Hearing loss in children with Down Syndrome. Int J Pediatr Otorhinolaryngol, 2001; 61(3): 199-205

14. Shott SR: Down syndrome: common otolaryngologic manifestations. Am J Med Genet C Semin Med Genet, 2006; 142C(3): $131-40$
15. Roberts JE, Long SH, Malkin C: A comparison of phonological skills of boys with fragile $\mathrm{X}$ syndrome and Down syndrome. J Speech Lang Hear Res, 2005; 48(5): 980-95

16. Chapman RS, Seung HK, Schwartz SE, Bird EK: Predicting language production in children and adolescents with Down syndrome: the role of comprehension. J Speech Lang Hear Res, 2000; 43(2): 340-50

17. Miolo G, Chapman RS, Sindberg HA: Sentence comprehension in adolescents with Down syndrome and typically developing children: role of sentence voice, visual context, and auditory-verbal short-term memory. J Speech Lang Hear Res, 2005; 48(1): 172-88

18. Dodd B, Thompson L: Speech disorders in children with Down syndrome. J Intellect Disabil Res, 2001; 45(4): 308-16

19. Bunton K, Leddy M: An evaluation of articulatory working space area in vowel production of adults with Down syndrome. Clin Linguist Phon, 2011; 25(4): 321-34

20. Barnes EF, Roberts J, Mirrett P et al: A comparison of oral structure and oral-motor function in young males with Fragile X syndrome and Down syndrome. J Speech Lang Hear Res, 2006; 49(4): 903-17

21. Welsh TN, Elliott D, Simon DA: Cerebral specialization and verbal-motor integration in adults with and without Down syndrome. Brain Lang, 2003; 84(2): 152-69

22. Bunn L, Welsh T, Simon DA et al: Dichotic ear advantages in adults with Down syndrome predict speech production errors. Neuropsychology, 2003; 17(1): 32-38

23. Elliott D, Gray S, Weeks DJ: Cerebral specialization for speech perception and movement organization in adults with Down syndrome. Cortex, 1993; 29(1): 103-13

24. Elliott D, Weeks DJ, Elliott CL: Cerebral specialization in individuals with Down syndrome. Am J Ment Retard, 1987; 92(3): 263-71

25. Bunn L, Simon DA, Welsh TN et al: Speech production errors in adults with and without Down syndrome following verbal, written and pictorial cues. Dev Neuropsychol, 2002; 21(2): $157-72$

26. Groen MA, Alku P, Bishop DV: Lateralization of auditory processing in Down syndrome: a study of T-complex peaks Ta and Tb. Biol Psychol, 2008; 79(2): 148-57

27. Keller-Bell Y, Fox RA: A preliminary study of speech discrimination in youth with Down syndrome. Clin Linguist Phon, 2007; 21(4): 305-17 
28. Jarrold C, Baddeley AD, Phillips CE: Verbal short-term memory in Down syndrome: a problem of memory, audition, or speech? J Speech Lang Hear Res, 2002; 45: 531-44

29. Jarrold C, Baddeley AD, Hewes AK: Genetically dissociated components of working memory: evidence from Down and Williams syndrome. Neuropsychologia, 1999; 37(6): 637-51

30. Jarrold C, Cowan N, Hewes A, Riby D: Speech timing and verbal short-term memory: evidence for contrasting deficits in Down syndrome and Williams syndrome. J Mem Lang, 2004; 51(3): 365-80

31. Purser HR, Jarrold C: Impaired verbal short-term memory in Down syndrome reflects a capacity limitation rather than atypically rapid forgetting. J Exp Child Psychol, 2005; 91(1): $1-23$

32. Brock J, Jarrold C: Serial order reconstruction in Down syndrome: evidence for a selective deficit in verbal short-term memory. J Child Psychol Psychiatry, 2005; 46(3): 304-16

33. Carlesimo GA, Marotta L, Vicari S et al: Long-term-memory in mental retardation: evidence for a specific impairment in subjects with Down syndrome. Neuropsychologia, 1997; 35(1): 71-79

34. Laws G, Bishop DVM: A comparison of language abilities in adolescents with Down syndrome and children with specific language impairment. J Speech Lang Hear Res, 2003; 46(6): 1324-39
35. Laws G: Contributions of phonological memory, language comprehension and hearing to the expressive language of adolescents and young adults with Down syndrome. J Child Psychol Psychiatry, 2004; 45(6): 1085-95

36. Laws G, Gunn D: Relationships between reading, phonological skills and language development in individuals with Down syndrome: a five-year follow-up study. Reading Writing, 2002; 15: $527-48$

37. Laws G, Gunn D: Phonological memory as a predictor of language comprehension in Down syndrome: a five-year followup study. J Child Psychol Psychiatry, 2004; 45(2): 326-37

38. Kittler P, Krinsky-McHale SJ, Devenny DA: Semantic and phonological loop effects on verbal working memory in middleage adults with mental retardation. Am J Ment Retard, 2004; 109(6): 467-80

39. Vicari S: Memory development and intellectual disabilities. Acta Paediatr Suppl. 2004; 445: 60-64

40. Conners FA, Rosenquist CJ, Arnett L et al: Improving memory span in children with Down syndrome. J Intellect Disabil Res, 2008; 52(3): 244-55

41. Chapman RS, Hesketh LJ, Kistler DJ: Predicting longitudinal change in language production and comprehension in individuals with Down syndrome: hierarchical linear modeling. J Speech Lang Hear Res, 2002; 45(5): 902-15

42. Alcock K: The development of oral motor control and language. Downs Syndr Res Pract, 2006; 11(1): 1-8

43. University of Wisconsin-Madison (2009). URL http://www.wisc.edu 